\title{
KAITAN PENDIDIKAN DAN KEPRIBADIAN MANUSIA DALAM MENCAPAI TUJUAN PENDIDIKAN NASIONAL
}

\author{
Oleh \\ Ni Nengah Selasih \\ Dosen pada Program Pascasarjana IHDN Denpasar
}

\begin{abstract}
Human nature, in terms of education, according Lengeveld is educabile animal, namely being able to be educated; educandum animal, the creature must be educated; education homo, that being on the side can and should be educated can and should educate. The role of education in fostering personality summed up in the goals of education derived or determined by the principle of ontological view and axiologis. Man is the subject, as well as objects of education. Cultured adult human is the subject of education in the sense of responsible education. Human undertaking to foster the commuity, preserve the natural environment together, primarily responsible for the dignity of humanity.

Based on the analysis of the structure of the human soul and personality, the human behavior is determined by the source and the id, ego, and superego. Therefore, compulsory education is deepened to better understand of human behavior or character. In particular, for educational purposes, to understand human nature, personality, means to understand individual interests, aspirations, potentials, and personal identity, and are fundamental to the effectiveness of the educatonal process, an obligation also to respect the dignity, personality, and uniqueness of a person in order to self-realization.

Science of life for science education is a very valueble complementation. Pedagogic without the same life science with practice without theory. Education without understanding the human means to build something without knowing for what, how, and why people are educated. Without an understanding of the people, the unique nature of the individual, and the potential that it will be fostered, then education would be misdirected. Even without the good sense, then education would rape human nature.
\end{abstract}

Keywords: education, human nature, personality

\section{PENDAHULUAN}

Manusia sebagai satu organisme yang hidup di dalam antar hubungan dan antar aksi sosial, baik terhadap lingkungan fisik, lingkungan alam, maupun lingkungan sosial. Dengan demikian, manusia tidak hanya dianalisa secara obyektif, sebagaimana adanya, sebagai pribadi manusia an sich. Melainkan mengerti manusia dalam konteks keseluruhan realita dalam mana manusia aktif dan dinamis melakukan peranan sebagai subyek. Sebagai subyek yang mempunyai potensi-potensi lahir bathin, manusia melakukan prakarsa, rasa, dan karsa, bahkan juga karya dan prestasi karena 
dorongan-dorongan yang juga amat kompleks. Dorongan-dorongan tersebut dapat terjadi karena faktor-faktor obyektif (kebutuhan), dapat pula karena faktor-faktor subyektif (cinta, pengabdian). Bahkan dapat juga karena alasan-alasan moral (tanggung jawab), kewajiban, harga diri, dan nilai-nilai. Dengan demikian, memahami manusia haruslah dalam hubungannya dengan dunia manusia, yakni kebudayaan manusia secara keseluruhan.

Dunia manusia dalam makna yang mencakup scope untuk mengadakan reorientasi atas dimensi-dimensi ruang lingkup kesadaran manusia, sehingga hakikat manusia menurut pandangan Anthropologia Metafisika dan filsafat kemanusiaan (Langeveld) tentang hakikat manusia integritas antara kesadaran-kesadaran, bahwa manusia sebagai makhluk individu; makhluk social; makhluk susila

Merumuskan tujuan pendidikan yang universal, maka rumusan tujuan tersebut harus mengandung ketiga inti hakiki kemanusiaan sehingga tujuan pendidikan untuk membimbing anak ke arah kedewasaan, yang menurut Langeveld mempunyai arti membentuk individu yang berkesadaran sosial dan susila atau membentuk pribadi sosial yang bermoral. Langeveld juga mengemukakan hakikat kemanusiaan ditinjau dari segi pendidikan, yaitu bahwa manusia pada hakikatnya adalah

1. Animal educabile, yaitu makhluk yang dapat dididik.

2. Animal educandum, yaitu makhluk yang harus dididik.

3. Homo education, yaitu makhluk yang di samping dapat dan harus dididik juga dapat dan harus mendidik.

\section{PEMBAHASAN}

\section{Hakikat Manusia}

Dimensi kesadaran manusia, atau ketiga kesadaran manusia merupakan essensia martabat manusia (the essence of human dignity). Manusia sebagai individu, sebagai pribadi adalah suatu kenyataan yang paling riil dalam kesadaran manusia. Malahan ada kecendrungan bahwa manusia menganggap pusat orientasi, melalui introspeksi dan proyeksi (istilah dalam ilmu jiwa) adalah dirinya sendiri sebagai subyek. Makin manusia sadar akan diri sendiri sesungguhnya manusia makin sadar akan kesemestaan, karena posisi manusia adalah bagian yang tidak terpisahkan dari semesta. Antar hubungan dan antar aksi pribadi melahirkan konsekuensi-konsekuensi seperti hak (asasi) dan kewajiban, norma-norma moral, nilai-nilai sosial, bahkan juga nilai-nilai supernatural berfungsi untuk manusia.

Perwujudan manusia sebagai makhluk sosial terutama nampak dalam kenyataan bahwa tidak pernah ada manusia yang mampu hidup (lahir dan proses dibesarkan) tanpa bantuan orang lain. Orang lain yang dimaksud paling sedikit adalah orang tuanya, keluarganya sendiri. Manusia sebagai makhluk sosial, di samping berarti bahwa manusia hidup bersama, maka sifat interdependensi itu merupakan watak inherent kesadaran sosial. Sebab, manusia tidak hanya interdependensi dalam materiil-ekonomis demi kebutuhan biologis jasmaniah. Melainkan lebih-lebih mengandung makna psikologis, yakni dorongan-dorongan cinta dan dicintai, di mana kebahagiaan terutama terletak dalam kepuasan rohani.

Hidup bersama dalam hubungan, antar aksi, dan interdependensi mengandung konsekuensi-konsekuensi sosial, baik dalam arti positif maupun negatif. Idealnya, hidup bersama adalah keadaan harmonis, rukun, dan sejahtera. Tetapi dapat pula terjadi segi negatif antar hubungan dan antar aksi itu terjadi dalam kehidupan sosial. Keadaan positif dan negatif adalah perwujudan dari pada nilai-nilai dan sekaligus watak individualitas manusia. Proses disharmonis terjadi hanyalah sebagai akibat pergeseran-pergeseran yang tajam dan bahkan mungkin pertentangan-pertentangan yang terjadi dalam proses antar hubungan dan antar aksi sosial, karena sifat-sifat individualitas 
manusia. Kehidupan individu di dalam antar hubungan sosial memang tidak usah kehilangan identitasnya. Sebab, kehidupan sosial adalah realita sama riilnya dengan kehidupan individu itu sendiri.

Pribadi manusia yang hidup bersama melakukan antar hubungan dan antar aksi, baik langsung maupun tidak langsung. Dalam proses antar hubungan dan antar aksi itu, tiap pribadi membawa identitas, kepribadian masingmasing. Oleh karena itu, keadaan yang cukup heterogin akan terjadi sebagai konsekuensi tindakan-tindakan masing-masing pribadi. Keadaan interdependensi, kebutuhan manusia lahir bathin yang tiada batasnya akan berlangsung terus secara kontinyu. Demi ketertiban, kesejahteraan manusia, maka di dalam masyarakat ada nilai-nilai, norma-norma.

Menurut Gordon Allport dalam (Philip G. Zimbardo,1979:296), bahwa memang manusia memiliki sifat--sifat dasar atau tabiat yang sama. Sifat-sifat dasar ini ditampilkan dalam sikap yang secara totalitas terlihat sebagai ciri-ciri kepribadian individu dan kemudian terangkum dalam sikap kelompok. Adanya perbedaan individu pada dasarnya disebabkan oleh adanya perbedaan situasi lingkungan yang dihadapi masing-masing. Merujuk kepada temuan ini, barangkali pemahaman sifat-sifat dasaryang merupakan ciri khas yang ada pada manusia dapat dikaitkan dengan konsep fitrah dalam pandangan Islam. Jika hal ini dapat diterima, maka pembentukan sikap dan tingkah laku keagamaan dapat dilakukan sejalan dengan fitrah tersebut bila situasi lingkungan dibentuk sesuai dengan ketentuan ajaran agama yang prinsipil, yaitu ketauladan.

Dalam pandangan psikologi agama, ajaran agama memuat norma-norma yang dijadikan pedoman oleh pemeluknya dalam bersikap dan bertingkah laku. Norma-norma tersebut mengacu kepada pencapaian nilai-nilai luhur yang mengacu kepada pembentukan kepribadian dan keserasian hubungan sosial dalam upaya memenuhi ketaatan kepada Zat Yang Supernatural. Dengan demikian, sikap keagamaan merupakan kecenderungan untuk memenuhi tuntutan dimaksud. Tetapi dalam kenyataan hidup sehari tak jarang dijumpai adanya penyimpangan yang terjadi. Sikap keagamaan yang menyimpang terjadi bila sikap seseorang terhadap kepercayaan dan keyakinan terhadap agama yang dianutnya mengalami perubahan. Perubahan sikap seperti itu dapat terjadi pada orang perorang (dalam diri individu) dan juga pada kelompok atau masyarakat. Sedangkan perubahan sikap itu memiliki tingkat kualitas dan intensitas yang mungkin berbeda dan bergerak secara kontinyu dari positif melalui areal netral ke arah negatif (Mar'at,1981:17).

\section{Kepribadian dan Pendidikan}

Ilmu pengetahuan dan filsafat tentang hakikat manusia, dijadikan dasar untuk pembinaan kepribadian manusia. Mengerti struktur jiwa dan hakikat manusia, pembinaan aspek-aspek kepribadian menjadi lebih terarah pada sasaran yang tepat, serta pendidikan sebagai prasarana usaha pembinaan kepribadian itu. Peranan pendidikan dalam pembinaan kepribadian terutama tersimpul dalam usahanya merealisasikan tujuan pendidikan. Tujuan pendidikan secara umum, terutama untuk membina kepribadian manusia yang sempurna. Pengertian dan kriteria sempurna itu ditentukan oleh dasar pandangan masing-masing pribadi, masyarakat, bangsa, pada suatu tempat dan waktu. Oleh karena itu,penentuan tujuan pendidikan bersumber atau ditentukan oleh asas-asas pandangan ontologis dan axiologis. Jadi, penetapan itu berlatar belakang filosofis. Konsekuensinya, pastilah aka nada variasi interpretasi, baik mengenai makna pengertian sempurna, maupun aspek-aspek lain dari pada rumusan tujuan pendidikan.

Pendidikan yang terutama dianggap sebagai proses pengoperasian kebudayaan, pengembangan ilmu pengetahuan berarti 
membina pribadi manusia untuk mengerti, berpengetahuan dalam arti seluas-luasnya. Berpengetahuan atau tahu adalah asas utama untuk kebaikan menuju kesempurnaan. Pandangan demikian ditanamkan oleh Socrates bahwa pengetahuan adalah kebajikan. Socrates mensinthesakan ilmu dan nilai dalam prinsip bahwa ilmu (tahu) adalah kunci kabajikan, sedangkanilmu hanya mungkin dimiliki melalui pendidikan, baik belajar melalui pendidikan formal maupun informal. Sedemikian jauh, ilmu pengetahuan mempunyai nilai-bina atas kepribadian. Dengan ilmu, sikap kritis-rasional, broadmindedness (lapang dada), obyektif, akan berkembang. Di samping itu, ilmu pengetahuan selalu mengandung nilai-nilai praktis di dalam kehidupan, baik sebagai pribadi maupun sebagai warga masyarakat.

Dalam masyarakat bangsa-bangsa modern, lebih-lebih dalam rangka menjelang masa depan yang super modern, pendidikan dianggap satu-satunya media untuk membina keseimbangan antara bangsa yang maju di satu pihak dan bangsa yang ketinggalan di lain pihak. Dengan perkataan lain, bangsa yang underdeveloped atau developing countries berusaha mengejar ketinggalan mereka melalui pendidikan. Terutama belajar dari bangsa yang maju itu tentang apa yang mereka capai sekarang.

Pendidikan dalam wujudnya, selalu bertujuan membina kepribadian manusia, baik demi ultimate-goal maupun bagi tujuan-tujuan dekat. Tujuan akhir pendidikan adalah kesempurnaan pribadi. Prinsip ini terutama berpangkal pada asas self-realisasi, yakni merealisasi potensi-potensi yang sudah ada di dalam martabat kemanusiaannya. Potensipotensi itu, baik berupa potensi-potensi intelektual, mental, rasa, karsa, maupun kesadaran moral, bahkan juga aspek-aspek keterampilan phisik dan perkembangan jasmaniah. Essensia kepribadian manusia yang tersimpul dalam aspek-aspek: individualitas, sosialitas, dan moralitas hanya mungkin menjadi realita (tingkah laku, sikap) melalui pendidikan yang diarahkan kepada masing-masing essensia itu. Harga diri, kepercayaan pada diri sendiri, rasa tanggung jawab, dan sebagainya juga akan tumbuh dalam kepribadian manusia melalui proses pendidikan. Dunia dan kebudayaan modern tidak sedikitpun meragukan nilai pendidikan bagi kehidupan umat manusia. Kepemimpinan suatu bangsa dan proses regenerasi mereka tidak mungkin tanpa pendidikan. Bahkan secara individual, tiada pekerjaan di dalam kehidupan manusia yang akan efektif dilaksanakan seseorang termasuk bahasa/bicara, berjalan, tanpa melalui proses pendidikan. Hal tersebut akan lebih-lebih berlaku bagi suatu pekerjaan sosial, profesi, dalam semua bidang dan semua tingkatan. Dalam membina kepribadian, pendidikan mematangkan kepribadian yang tersimpul dalam derajat integritas dan kebijaksanaan sebagai tingkat ideal. Ilmu pengetahuan mempercepat proses itu.

Hakikat manusia adalah integritas antara wataknya sebagai makhluk individu, sebagai makhluk sosial, dan sebagai makhluk susila. Ketiga essensia ini adalah sebagai martabat manusia (human-dignity), kodrat manusia, yang bersifat potensial. Seluruh perwujudan dan tingkah laku manusia adalah pengejawantahan ketiga essensia itu dalam kadar perbandingan yang berbeda-beda di dalam realisasinya. Artinya, ada seseorang yang realisasi aspek pertama amat menonjol; ada pula aspek kedua sebagai manusia sosial; ataupun aspek ketiga yang menonjol. Namun, idealnya adalah keseimbangan antara ketiga aspek tersebut. Essensia yang potensial itu akan dipengaruhi oleh lingkungan dalam usaha realisasinya menjadi kenyataan sebagai tingkah laku (aktualitas).

\section{Pandangan Filsafat tentang Hakikat Manusia}

Manusia adalah subyek pendidikan, sekaligus sebagai obyek pendidikan. Manusia 
dewasa yang berkebudayaan adalah subyek pendidikan dalam arti yang bertanggung jawab menyelenggarakan pendidikan. Mereka berkewajiban secara moral atas perkembangan pribadi anak-anaknya, generasi penerusnya. Manusia dewasa yang berkebudayaan, terutama yang berprofesi keguruan (pendidikan) bertanggungjawab formal untuk melaksanakan misi pendidikan sesuai dengan tujuan dan nilainilai yang dikehendaki masyarakat bangsa itu.

Manusia yang belum dewasa, dalam proses perkembangan kepribadiannya, baik menuju pembudayaan maupun proses kematangan dan integritas adalah "obyek" pendidikan. Artinya, mereka adalah sasaran atau bahan yang dibina. Meskipun disadari bahwa perkembangan kepribadian adalah selfdevelopment melalui self-activities. Jadi, sebagai subyek yang sadar mengembangkan diri sendiri. Proses pendidikan yang berlangsung di dalam antar aksi yang pluralistis (antarasubyek dengan lingkkungan alamiah, sosial, dan cultural ditentukan oleh aspek manusianya. Sebab, kedudukan manusia sebagai subyek di dalam masyarakat, bahkan dalam alam semesta, memberikan konsekuensi tanggung jawab yang besar bagi manusia. Manusia mengemban amanat untuk membina masyarakat, memelihara alam lingkungan hidup bersama, terutama bertanggung jawab atas martabat kemanusiaannya (human dignity).

Perwujudan kepribadian seseorang nampak dalam keseluruhan pribadi manusia dalam antar hubungan dan antar aksi dengan lingkungan hidupanya. Apa yang dismpulkan sebagai pengertian itu lebih bersifat statis, sedangkan usaha untuk mengerti manusia secara aktif dan terus menerus di dalam antar hubungan dan antar aksi sesama itu bersifat dinamis. Asas dinamis merupakan essensi watak manusia yang terus berkembang, bertumbuh, dan menuju integritas kepribadiannya. Usaha manusia untuk mengerti dirinya itu adalah usaha lebih jauh atau termasuk bidang ontology. Sebab, sesungguhnya pribadi manusia itu adalah satu realita; yakni realita di dalam makrokosmos. Perbedaannya dengan realita yang lain di dalam alam semesta itu, walaupun relatif banyak, namun pada prinsipnya ialah kesadaran diri sendiri. Karena itulah manusia bersifat unik.

\section{Pandangan Ilmu Pengetahuan tentang Hakikat Manusia}

Ilmu sosial dasar (basicsocial-sciences) dan humanities adalah ilmu yang mengarahkan perhatian dan orientasinya demi pengertian yang lebih baik tentang manusia dan dunianya. Ilmu sosial dasar (basicsocial-sciences) dan humanities bidang yang menyelidiki secara khusus dan mendalam kehidupan budaya manusia, yakni tentang manusia dan dunianya termasuk antar hubungan dan antar aksi manusia dan sesamanya, dengan alam sekitar, dengan nilai-nilai. Usaha ilmu itu dalam rangka pembinaan manusia ideal merupakan program utama dalam pendidikan modern. Orientasi yang memusat pada pembinaan manusia, baik pengertian tentang kepribadian maupun antar manusia adalah konsekuensi atas pandangan bahwa manusia adalah subyek dalam alam semesta.

Manusia tidak terpisahkan dari lingkungan hidupnya, baik lingkungan alamiah, maupun lingkungan phisik/materiil; dan lebih-lebih lingkungan sosial (manusia dan nilai-nilai yang ada). Tingkah laku manusia sebagai perwujudan atau representasi kepribadiannya adalah serentetan reaksi-reaksinya atas semua antar hubungan dan antar aksi dengan lingkungan hidupnya.

Berdasarkan analisis atas struktur jiwa manusia atau kepribadian itu nyatalah bahwa tingkah laku manusia bersumber dan ditentukan oleh ketiga bagian (Id, Ego, dan Superego). Setiap motif, cita-cita dan tingkah laku manusia bersumber atas dorongan-dorongan asasi ketiga bagian jiwaitu. Oleh sebab itu, pendidikan wajib diperdalam untuk lebih memahami tingkah laku atau watak manusia. Secara 
khusus, untuk tujuan-tujuan pendidikan, memahami hakikat manusia, kepribadian, berarti mengerti kepentingan-kepentingan individu, minat, cita-cita, potensi, dan identitas pribadi. Pengertian itu merupakan dasar bagi efektifnya pengertian proses pendidikan, merupakan kewajiban pula untuk menghormati martabat, kepribadian, dan keunikan seseorang dalam rangka self-realisasi.

Sebagaimana diketahui bahwa ilmu jiwa bagi ilmu pendidikan adalah suatu komplementasi yang amat bernilai. Pedagogik tanpa ilmu jiwa sama dengan praktek tanpa teori. Pendidikan tanpa mengerti manusia, berarti membina sesuatu tanpa mengerti untuk apa, bagaimana, dan mengapa manusia dididik. Tanpa pengertian atas manusia, baik sifat-sifat individualnya yang unik, maupun potensi-potensi yang justru akan dibina, pendidikan akan salah arah. Bahkan tanpa pengertian yang baik, pendidikan akan memperkosa kodrat manusia. Manusia adalah makhluk yang disebut dengan istilah yang bermacam-macam seperti homo faber, homo sapiens, homo rational, animale social, mencerminkan gambaran apa yang terkandung sebagai sifat asasi manusia.

\section{SIMPULAN}

Manusia sebagai satu organisme yang hidup di dalam antar hubungan dan antar aksi sosial, baik terhadap lingkungan fisik, lingkungan alam, maupun lingkungan sosial. Manusia aktif dan dinamis melakukan peranan sebagai subyek mempunyai potensi-potensi lahir bathin, melakukan prakarsa, rasa, dan karsa, bahkan juga karya dan prestasi karena dorongan yang amat kompleks, dan karena alasan moral (tanggung jawab), kewajiban, harga diri, dan nilai-nilai. Hakikat manusia menurut pandangan Anthropologia Metafisika dan filsafat kemanusiaan (Langeveld) tentang hakikat manusia integritas antara kesadaran, bahwa manusia sebagai makhluk individu, makhluk social, makhluk susila
Merumuskan tujuan pendidikan yang universal, maka rumusan tujuan tersebut harus mengandung ketiga inti hakiki kemanusiaan sehingga tujuan pendidikan untuk membimbing anak ke arah kedewasaan. Langeveld juga mengemukakan hakikat kemanusiaan ditinjau dari segi pendidikan, yaitu bahwa manusia pada hakikatnya adalah Animal educabile, yaitu makhluk yang dapat dididik; Animal educandum, yaitu makhluk yang harus dididik; Homo education, yaitu makhluk yang di samping dapat dan harus dididik juga dapat dan harus mendidik.

Ilmu pengetahuan dan filsafat tentang hakikat manusia, dijadikan dasar untuk pembinaan kepribadian manusia dengan mengerti struktur jiwa dan hakikat manusia, pembinaan aspek kepribadian menjadi lebih terarah pada sasaran yang tepat, serta pendidikan sebagai prasarana usaha pembinaan kepribadian itu. Peranan pendidikan dalam pembinaan kepribadian terutama tersimpul dalam usahanya merealisasikan tujuan pendidikan bersumber atau ditentukan oleh asas-asas pandangan ontologis dan axiologis.

Pandangan Socrates bahwa pengetahuan adalah kebajikan, ilmu dan nilai dalam prinsip bahwa ilmu (tahu) adalah kunci kabajikan, sedangkan ilmu hanya mungkin dimiliki melalui pendidikan, baik belajar melalui pendidikan formal maupun informal. Manusia adalah subyek pendidikan, sekaligus sebagai obyek pendidikan. Manusia dewasa yang berkebudayaan adalah subyek pendidikan dalam arti yang bertanggung jawab menyelenggarakan pendidikan. Manusia mengemban amanat untuk membina masyarakat, memelihara alam lingkungan hidup bersama, terutama bertanggung jawab atas martabat kemanusiaannya (human dignity).

Asas dinamis merupakan essensi watak manusia yang terus berkembang, bertumbuh, dan menuju integritas kepribadiannya. Usaha manusia untuk mengerti dirinya itu adalah usaha 
lebih jauh atau termasuk bidang ontology. Ilmu sosial dasar dan humanities adalah ilmu yang mengarahkan perhatian dan orientasinya tentang manusia dan dunianya yang menyelidiki secara khusus dan mendalam kehidupan budaya manusia.

Berdasarkan analisis atas struktur jiwa manusia atau kepribadian bahwa tingkah laku manusia bersumber dan ditentukan oleh ketiga bagian (Id, Ego, dan Superego). Oleh sebab itu, pendidikan wajib diperdalam untuk lebih memahami tingkah laku atau watak manusia. Secara khusus, untuk tujuan-tujuan pendidikan, memahami hakikat manusia, kepribadian, berarti mengerti kepentingan individu, minat, cita-cita, potensi, dan identitas pribadi dan merupakan dasar bagi efektifnya proses pendidikan, merupakan kewajiban pula untuk menghormati martabat, kepribadian, dan keunikan seseorang dalam rangka self-realisasi.

Ilmu jiwa bagi ilmu pendidikan adalah suatu komplementasi yang amat bernilai. Pedagogik tanpa ilmu jiwa sama dengan praktek tanpa teori. Pendidikan tanpa mengerti manusia, berarti membina sesuatu tanpa mengerti untuk apa, bagaimana, dan mengapa manusia dididik. Tanpa pengertian atas manusia, baik sifat-sifat individualnya yang unik, maupun potensi-potensi yang justru akan dibina, pendidikan akan salah arah. Bahkan tanpa pengertian yang baik, pendidikan akan memperkosa kodrat manusia.

\section{DAFTAR PUSTAKA}

Langeveld, Dr. M.J. tt. Мепији Kepemikiran Filsafat. Jakarta: PT Pembangunan

Mulyana, 2002. Kurikulum Berbasis Kompetensi. Konsep, Karakteristik, dan Implementasi. Bandung. PT. Remaja Rosdakarya.

Primary Education Quality Improvement Project (PEQIP). Mutu (Media Komunikasi dan Informasi Peningkatan Mutu Pendidikan Dasar). MUTU Vol.VII No.01 Edisi April-Juni 1998.

Tim Pengembang MKDP Kurikulum dan Pembelajaran. 2013. Kurikulum dan Pembelajaran. Rajawali Pers. PT Rajagrafindo Persada

Wiyani, Novan Ardy, 2011. Pengantar Ilmu Pendidikan Islami. Rancang Bangun Konsep Pendidikan MonokhomikHolistik. Penerbit: Bumiayu, STKIP Islam Bumiayu

Wiyani, Novan Ardy, 2012. Manajemen Pendidikan Karakter. Konsep dan Implementasinya di Sekolah. Penerbit: Pedagogia, PT Pustaka Insan Madani, Anggota IKAPI) Yogyakarta. 